\title{
Pengaruh Model Active Learning dan Kecerdasan Majemuk Logis Matematis Terhadap Kemampuan Berpikir Kritis Siswa Pada Pembelajaran Abad 21
}

\author{
${ }^{1}$ Siti Nawarul Uyun, ${ }^{2}$ Muhamad Ali, ${ }^{3}$ Badarudin \\ 1'Email: Sitinawarul@gmail.com, ${ }^{2}$ muhamadali@hamzanwadi.ac.id, ${ }^{3}$ badarudin@hamzanwadi.ac.id \\ ${ }^{1}$ SDN 3 Pringgabaya, ${ }^{2,3}$ Universitas Hamzanwadi
}

\begin{abstract}
This research aims to determine the influence of active learning models and compound intelligence on students' critical thinking abilities. This type of research uses a type of quantitative research method experiment with treatment level design $2 x 2$. The population and research sample are all grades V students of SDN 6 Pringgabaya divided into control and experiment classes. The data collection techniques used are questionnaires and tests. Technical data analysis uses descriptive and differential analysis. The hypothesis test used is a two-lane ANOVA. The data in the experiment and control classes are normal and homogeneous. The results showed a difference in learning outcomes between students who studied using active learning models and students who studied using a direct learning model because $F h(K)=34,0593>4.15$, data shows there is an interaction between the model and logical-mathematical compound intelligence because Fh (interaction) $=40.0293>4.15$, the data shows no very significant difference because $F h(b)=0.75<4.15$, then there are no differences that show there are differences in the learning outcomes of students who have high mathematical, logical compound intelligence and low mathematical logic, and the data shows there are differences between active learning model groups and direct learning with high logical-mathematical compound intelligence with low due to $F h(A K)=34,0593>3.32$. Thus, active learning models and logical-mathematical compound intelligence profoundly affect students' critical thinking abilities.
\end{abstract}

Keywords: 21st-century learning, logical-mathematical compound intelligence, active learning and critical thinking of students.

\begin{abstract}
Abstrak
Penelitian ini bertujuan untuk mengetahui pengaruh model active learning dan kecerdasan majemuk terhadap kemampuan berpikir kritis siswa. Jenis penelitian ini menggunakan jenis penelitian kuantitatif metode eksperimen dengan desain treatment level 2x2. Populasi dan sampel penelitian yaitu seluruh siswa kelas V SDN 6 Pringgabaya yang dibagi menjadi kelas control dan eksperimen. Teknik pengumpulan data yang digunakan yaitu angket dan tes. Teknis analisis data mengunakan analisis deskriptif dan diferensial. Uji hipotesis yang digunakan yaitu ANAVA dua jalur. Data pada penelitian pada kelas eksperimen dan kontrol bersifat normal dan homogen. Hasil penelitian menunjukkan adanya perbedaan hasil belajar antara siswa yang belajar dengan menggunakan model active learning dengan siswa yang belajar dengan menggunakan model pembelajaran langsung karena $\mathrm{Fh}(\mathrm{K})=34,0593>4,15$, data menunjukkan ada interaksi antara model dengan kecerdasan majemuk logis-matematis karena Fh (interaksi) $=40,0293>4,15$, data menunjukkan tidak ada perbedaan yang sangat signifikan karena $\mathrm{Fh}(\mathrm{b})=0,75<4,15$, maka tidak terdapat perbedaan yang menunjukkan ada perbedaan hasil belajar siswa yang memiliki kecerdasan majemuk logis-matematis tinggi dan logis-matematis rendah, dan data menunjukkan terdapat perbedaan antara kelompok model active learning dan pembelajaran langsung dengan kecerdasan majemuk logismatematis tinggi dengan rendah karena $\mathrm{Fh}(\mathrm{AK})=34,0593>3,32$. Jadi, model abad 21 yaitu active learning dan kecerdasan majemuk logis-matematis sangat berpengaruh terhadap kemampuan berpikir kritis siswa
\end{abstract}




\section{Educatio: Jurnal IImu Kependidikan}

Vol. 16, No 1 Juli 2021, hal. 9-23

http://e-journal.hamzanwadi.ac.id/index.php/edc

e-ISSN: 2527-9998

DOI: 10.29408/edc.v16i1.2770

Kata Kunci: Pembelajaran abad 21, kecerdasan majemuk logis-matematis, active learning dan berpikir kritis siswa

\section{PENDAHULUAN}

Kualitas pendidikan di Indonesia pada tahun 2018 menurun karena berdasarkan survei PISA (Programme for International Student Assesment) bahwa, rata-rata SAINS 489 tetapi skor Indonesia memperoleh skor 396 berada pada peringkat ke 6 dari bawah, matematika indonesia peringkat ke-7 dari bawah dengan skor 379 (rata-rata OECD 489), dan skor terendah yang di peroleh Indonesia pada kategori membaca (rata-rata OECD 498). Data PISA menyebutkan bahwa Indonesia peringkat ke 74 dari 79 Negara sedangkan pada tahun 2015 peringkat ke 64 dari 72 Negara, berarti peringkat Indonesia dari tahun sebelumnya semakin menurun (Faradila, 2019). Hal ini memberikan indikasi tidak keseimbangan, karena kurikulum Indonesia sudah mengikuti perkembangan zaman yaitu kurikulum 2013 tetapi bukti nyata dari hasil survei PISA sangat rendah. Hal ini salah satunya disebabkan oleh metode belajar yang di gunakan tidak mengintegrasikan komponen HOTS tetapi masih menggunakan Lower-Medium Order sedangkan soal ujian nasional Indonesia mulai memakai HOTS (Higher Order Thinking Skills) (Putri, 2019). Fakta ini menjadi bukti bahwa sistem pendidikan harus di benahi secara menyeluruh, karena PISA adalah tolak ukur kegagalan uji coba pendidikan Indonesia yang selalu berganti setiap perubahan menteri.

Kondisi tersebut juga dipengaruhi oleh sistem pendidikan indonesia masih belum merata penerapannya antara sekolah yang di desa dengan di kota dalam segi sarana dan prasarana belajar. Fasilitas pendidikan di kota lebih maju dibandingkan dengan desa terutama di tempat terpencil hanya mengandalkan fasilitas seadanya dan belum lagi akses transportasi yang harus di gunakan oleh para siswa dan siswi. Sedangkan pendidikan di Indonesia sudah di arahkan kepada tekhnologi berdasarkan pada pembelajaran masa abad 21. Perkembangan tekhnologi informasi dan komunikasi menyebabkan dunia kerja menuntut perubahan kompetensi yaitu berpikir kritis, memecahkan masalah, kerjasama dan berkolaborasi.

Berdasarkan hasil observasi dan data hasil tes berpikir kritis siswa berbanding terbalik dengan apa yang di harapan pendidikan abad 21, diantaranya: pertama, guru masih menggunakan model pembelajaran yang berpusat pada guru, padahal tuntutan dan kebutuhan makin menuntut peserta didik untuk berpikir maju karena pendidikan telah masuk ke abad 21 dimana tekhnologi yang begitu pesat dan persaingan di dunia pendidikan dan dunia kerja begitu pesat bahkan kompetensi yang di harapkan dunia kerja juga ikut berubah. Kedua, buku paket yang di gunakan masih menggunakan buku paket revisi 2014 padahal sekolah sudah menggunakan revisi 2017, 2018 dan 2019. Ketiga, guru jarang sekali memperhatikan dan bahkan tidak pernah memperhatikan kecerdasan majemuk yang dimiliki oleh siswa padahal setiap anak memiliki kecerdasan yang berbeda dan anak yang satu tidak bisa di samakan dengan 


\section{Educatio: Jurnal IImu Kependidikan}

Vol. 16, No 1 Juli 2021, hal. 9-23

http://e-journal.hamzanwadi.ac.id/index.php/edc

e-ISSN: 2527-9998

DOI: 10.29408/edc.v16i1.2770

anak yang lain, jadi perlu sekali guru menuntun siswa untuk memperdalam kecerdasan yang dimiliki oleh siswa, bahkan kurikulum 2013 diarahkan untuk memberdayakan semua kompetensi yang dimiliki peserta didik (Hosnan, 2014). Keempat, siswa belum bisa memberikan argument berdasarkan pendapat sendiri. Kelima, pembelajaran tidak di kaitkan dengan kehidupan nyata siswa. Keenam, kemampuan berpikir kritis siswa rendah dibuktikan berdasarkan hasil tes berpikir kritis yang dilakukan oleh 32 siswa kelas V dengan siswa tuntas sebanya $43 \%$ dan siswa yang tidak tuntas sebanyak $57 \%$.

Hasil Observasi dan rendahnya kemampuan berpikir kritis siswa menuntut sekolah harus mampu menyiapkan peserta didiknya dalam menghadapi abad 21. Sejalan dengan itu, Kemendikbud Daryanto dan Karim (2017) merumuskan bahwa paradigma pembelajaran abad 21 menekankan kepada: (1) kemampuan peserta didik dalam mencari tahu dari berbagai sumber; (2) merumuskan permasalahan; (3) berpikir analitis; dan (4) kerjasama serta berkolaborasi. Keempat kompetensi tersebut dapat dicapai melalui empat model pembelajaran yaitu pembelajaran bermakna (Meaningful Learning), pembelajaran Aktif (Active Learning), pembelajaran langsung, Pembelajaran tidak langsung. Pembelajaran bermakna yaitu suatu proses pembelajaran dimana informasi yang baru diperoleh dihubungkan dengan pemahaman yang sudah dimiliki sebelumnya dalam proses pembelajaran.

Pembelajaran aktif merupakan segala bentuk pembelajaran yang dimana peserta didik aktif dalam proses pembelajaran. Pembelajaran langsung pandangan bahwa belajar bergantung pada pengalaman termasuk pemberian umpan balik. Pembelajaran tidak langsung merupakan kegiatan pembelajaran yang terjadi pada saat proses pembelajaran langsung tetapi tanpa perencanaan kegiatan khusus. Akan tetapi dari keempat model tersebut, pembelajaran Aktif (Active Learning) sangat efektif dalam meningkatkan berpikir kritis siswa.

Model pembelajaran tersebut juga dipengaruhi oleh salah satu faktor yaitu kecerdasan majemuk (Multiple Intelligincis) yang dimiliki oleh peserta didik. Kecerdasan majemuk berperan untuk memudahkan penerapan pembelajaran agar kompetensi yang diharapkan tercapai. Kecerdasan majemuk ada sembilan yang di kemukakan oleh Gadner dan Lazaer (Jamaris, 2017) diantaranya, kecerdasan linguistik (Kemampuan berbahasa), Kecerdasan Matematis-Logis (kemampuan menangani bilangan dan perhitungan, serta pola pemikirannya logis dan ilmiah), kecerdasan visual (melihat), kecerdasan musical, kecerdasan kinestetik (gerakan), kecerdasan interversonal (kemampuan mengerti dan memahami orang lain), kecerdasan naturalis (mengerti, memahami dan menikmati alam), dan kecerdasan spiritual (kemampuan untuk merasakan keberagaman dan macam-macam seseorang). Dari semua kecerdasan majemuk tersebut, kecerdasan yang berpengaruh terhadap kemampuan berpikir kritis yaitu kecerdasan majemuk logis-matematis. Seperti yang dicirikan Piaget (Jasmine, 2019: 


\section{Educatio: Jurnal IImu Kependidikan}

Vol. 16, No 1 Juli 2021, hal. 9-23

http://e-journal.hamzanwadi.ac.id/index.php/edc

e-ISSN: 2527-9998

DOI: 10.29408/edc.v16i1.2770

19) bahwa kecerdasan Logis-Matematis lebih mengarah kepada pemikiran kritis dan di gunakan sebagai metode ilmiah.

Berdasarkan uraian tersebut model pembelajaran abad 21 dan kecerdasan majemuk yang dimiliki siswa, sangat penting untuk diterapkan dan diketahui sebagai dasar dalam mempersiapkan siswa dalam menghadapi abad 21. Dimana, kemajuan teknologi informasi dan komunikasi mempengaruhi perkembangan di dunia pendidikan, sehingga sekolah berperan penting dalam meningkatkan mutu sekolah dan menjembatani siswa mampu menghadapi dunia kerja pada masa ini. Sehingga, penelitian ini bertujuan untuk mengetahui Pengaruh Model Active Learning dan Kecerdasan Majemuk Logis-Matematis Pada Pembelajaran Abad 21 Tehadap Kemampuan Berpikir Kritis Siswa di SDN 6 Pringgabaya.

\section{METODE PENELITIAN}

Penelitian ini meruapakan penelitian eksperimen quasi dengan membagi siswa menjadi dua kelompok yaitu eksperimen dan kontrol. Kelompok eksperimen merupakan kelompok yang diberi perlakuan menggunakan model active learning dan pembelajaran langsung. Sedangkan, kelompok kontrol merupakan kelompok yang tidak diberi perlakuan dengan menggunakan model yang biasanya digunakan oleh guru. Kemudian kedua kelompok tersebut di berikan tes dan hasilnya dibandingkan untuk menguji hipotesis pada penelitian ini. Desain penelitian menggunakan yaitu Treatment Level $2 \times 2$. Desain Treatment Level $2 \times 2$ merupakan dua atau lebih variabel bebas dimanipulasi secara simultan untuk menyelidiki pengaruhnya terhadap pariabel terikat (Andre \& Trisna, 2018: 11).

Tabel 1 Desain Treatment Level $2 \times 2$

\begin{tabular}{|l|c|c|c|}
\hline Variabel Atribut (B) & \multicolumn{2}{|c|}{ Variabel Eksperimen } & Jumlah \\
\hline & Perlakuan A1 & Perlakuan A2 & \\
\hline Kecerdasan Majemuk Tinggi $\left(B_{1}\right)$ & $A_{1} B_{1}$ & $A_{2} B_{1}$ & $A_{1}$ \\
\hline Kecerdasan majemuk rendah rendah $\left(B_{2}\right)$ & $A_{1} B_{2}$ & $A_{2} B_{2}$ & $B_{1}$ \\
\hline Jumlah & $A_{1}$ & $A_{2}$ & \\
\hline
\end{tabular}

Populasi yang digunakan yaitu populasi terbatas yaitu siswa kelas V. Teknik pengambilan sampel penelitian ini menggunakan simple random sampling yaitu adalah selurus siswa kelas V SDN 6 Pringgabaya dengan sampel kelas eksperimen pada kelas VA dengan jumlah 16 siswa dan kelas control nerasal dari kelas VB terdiri dari 16 siswa.

Penelitian ini terdiri dari tiga variabel yaitu dua variabel bebas dan 1 variabel terikat. Variabel bebas pada penelitian ini yaitu model active learning dan kecerdasan majemuk logismatematis. Sedangkan variabel terikat pada penelitian ini yaitu berpikir kritis siswa merupakan. Akan tetapi, kecerdasan majemuk logis matematis selain menjadi variabel bebas tetapi dikategorikan variabel moderator yang bisa mempengaruhi model dan kemampuan berpikir kritis.

Agar penelitian ini mencapai hasil yang ideal, peneliti melakukan validitas internal dan eksternal agar terjaga selama penelitian dan tidak mengalami berbagai kemungkinan. Validitas 


\section{Educatio: Jurnal IImu Kependidikan}

Vol. 16, No 1 Juli 2021, hal. 9-23

http://e-journal.hamzanwadi.ac.id/index.php/edc

e-ISSN: 2527-9998

DOI: 10.29408/edc.v16i1.2770

internal yang digunakan yaitu kematangan, sejarah, pemberian pre-test, pengaruh penggunaan instrumen, pemilihan subjek dan mortalitas (Creswell, 2009). Sedangkan eksternal diuji dengan cara membandingkan atau mencari kesamaan antara kriteria yang ada pada instrument dengan fakta-fakta empiris yang terjadi di lapangan.

Teknik pengumpulan data dalam penelitian ini dengan angket dan tes. Analisis data yang digunakan penelitian ini dengan analisis data deskriptif dan analisis data diferensial. Analisis data inferensial digunakan pada pengujian data statistik. Data statistik yang dilakukan yaitu uji validitas menggunakakan product moment, uji reabilitas menggunakan Sperman-Brown, uji normalitas menggunakan rumus Lilliefors. uji homogenitas menggunakan rumus perbandingan varians, dan uji hipotesis yang digunakan yaitu uji Analisis Varians (ANNAVA) dua jalur.

\section{HASIL DAN PEMBAHASAN}

1. Deskripsi Data

Data dalam penelitian ini diperoleh dengan memberikan instrumen tes dan angket. Intrumen tersebut untuk memperoleh data berupa, skor perolehan hasil berpikir kritis siswa dan skor kecerdasan majemuk logis-matematis. Skor perolehan hasil kemampuan berpikir kritis siswa ditentukan dari skor kemampuan akhir yang dihasilkan melalui kegiatan pascates. Data perolehan hasil kemampuan dikelompokkan menjadi: 1) skor perolehan hasil soal kemampuan berpikir kritis kelas eksperimen dengan model active learning, 2) skor perolehan hasil belajar kemampuan berpikir kritis kelas kontrol dengan model pembelajaran langsung, 3) skor perolehan kecerdasan majemuk logis-matematis pada kelas eksperimen, 4) skor perolehan kecerdasan majemuk logis-matematis pada kelas kontrol. Adapun gambaran hasil penelitian sebagai berikut:

\section{a. Hasil Belajar Kemapuan Berpikir Kritis}

\section{1) Data Kemampuan Awal Siswa}

Kemampuan awal (postest) merupakan tes yang diberikan kepada siswa baik kelas eksperimen maupun kontrol sebelum diberi perlakuan atau sebelum materi diajarkan. Data kemampuan awal ini merupakan skor yang diperoleh masing-masing siswa pada prates tersebut. Pretest ini dilakukan untuk mengetahui kemampuan awal siswa pada kelas eksperimen dan kontrol sehingga dapat mendukung bahwa subjek penelitian yang diambil memiliki karakteristik yang homogen. Berikut ini diuraikan data tes kemampuan awal untuk kedua kelompok. Kemampuan awal kelas eksperimen dan kontrol disajikan dalam Tabel 2.

Tabel 2 Hasil Pretest Kemampuan Berpikir Kritis Siswa

\begin{tabular}{|c|c|c|c|c|}
\hline Kelas & Skor Minimal & Skor Maxsimal & Rata-Rata & N \\
\hline Eksperimen & 34 & 86 & 60,63 & 16 \\
\hline Kontrol & 34 & 88 & 67,31 & 16 \\
\hline
\end{tabular}

Berdasarkan Tabel 2 dapat diketahui hasil kemampuan awal siswa pada pretest kelas eksperimen memiliki nilai rata-rata 60,63, sedangkan untuk kelas kontrol memiliki rata-rata nilai sebesar 67,31. Berdasarkan data pretest yang telah dipaparkan diatas dapat dilihat, 


\section{Educatio: Jurnal IImu Kependidikan}

Vol. 16, No 1 Juli 2021, hal. 9-23

http://e-journal.hamzanwadi.ac.id/index.php/edc

e-ISSN: 2527-9998

DOI: 10.29408/edc.v16i1.2770

bahwa rata-rata skor pretest untuk kelas kontrol lebih tinggi dari pada kelas eksperimen. Perbedaan skor rata-rata yang dimiliki oleh kedua kelas tidak terlalu signifikan. Berdasarkan hasil ini, dapat disimpulkan bahwa kemampuan awal kelas kontrol dan kelas eksperimen adalah homogen.

\section{2) Kemampuan Akhir Siswa}

Kemampuan akhir (postest) merupakan tes yang diberikan kepada siswa baik kelas eksperimen maupun kontrol sesudah diberi perlakuan atau sesudah materi diberikan. Data kemampuan akhir siswa ini merupakan skor yang diperoleh masing-masing siswa pada postest. Data ini bertujuan untuk mengetahui besar kemampuan akhir siswa kelas kontrol dan eksperimen, selain itu bertujuan juga mengetahui sebaran sampel berdasarkan atas skor yang diperoleh. Berikut ini diuraikan data tes kemampuan berpikir kritis siswa setelah perlakuan untuk kelompok eksperimen dan kontrol.

Tabel 3 Hasil Tes Kemampuan Berpikir Kritis Siswa Setelah Perlakuan

\begin{tabular}{|c|c|c|c|c|}
\hline Kelas & $\begin{array}{c}\text { Skor } \\
\text { Minimal }\end{array}$ & $\begin{array}{c}\text { Skor } \\
\text { Maxsimal }\end{array}$ & Rata-Rata & N \\
\hline Eksperimen & 84 & 95 & 92,56 & 16 \\
\hline Kontrol & 84 & 95 & 90,43 & 16 \\
\hline
\end{tabular}

Berdasarkan Tabel 3 dapat diketahui hasil kemampuan akhir siswa pada kelas eksperimen memiliki nilai rata-rata kemampuan berpikir kritis yang diperoleh kelompok kelas ekperimen adalah 92,56 sedangkan untuk kelas kontrol memiliki rata-rata nilai sebesar 90,43 . Berdasarkan data hasil tes kemampuan berpikir kritis pada tabel 3, dapat dilihat bahwa rata-rata skor akhir untuk kelas kontrol lebih rendah dari pada kelas eksperimen, sehingga dapat dikatakan bahwa kemampuan akhir kelas eksperimen dan kelas kontrol berbeda. Dari nilai rata-rata yang dimiliki oleh kedua kelas tersebut, baik kelas eksperimen maupun kelas kontrol mengalami peningkatan. Peningkatan nilai rata-rata lebih tinggi dialami oleh kelas eksperimen. Hal tersebut terjadi karena proses belajar mengajar yang dilaksanakan pada kelas.

Perbandingan nilai rata-rata kemampuan awal (pretest) dan kemampuan akhir (postest) antara kelas kontrol dan eksperimen dapat divisualisasikan pada grafik 3.1 berikut.

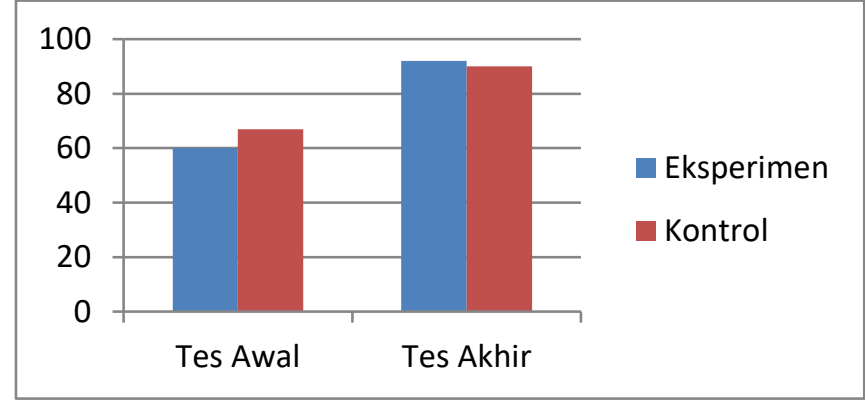

Grafik 1 Perbandingan Kemampuan Berpikir Kritis awal dan Akhir 


\section{b. Hasil Angket kecerdasan Majemuk Logis-Matematis}

Hasil angket kecerdasan majemuk logis-matematis digunakan untuk mengetahui siswa yang memiliki kecerdasan logis-matematis tinggi dan rendah pada kelas kontrol dan kelas eksperimen. Selain itu, agar kelas kontrol dan eksperimen homogen. Berikut ini diuraikan data angket kecerdasan majemuk pada tabel 4.

Tabel 4 Hasil Angket Kecerdasan Majemuk Logis-Matematis

\begin{tabular}{|c|c|c|}
\hline Responden & Tinggi & Rendah \\
\hline Eksperimen & $1,2,3,5,6,8,9,10=8$ & $4,7,11,12,13,14,15,16=8$ \\
\hline Kontrol & $1,2,3,4,5,6,11,15=8$ & $7,8,9,10,12,13,14,16=8$ \\
\hline Jumlah & 16 & 16 \\
\hline
\end{tabular}

Berdasarkan tabel 4, Siswa yang memiliki kecerdasan majemuk logis-matematis tinggi berjumlah 16 siswa dan kecerdasan majemuk logis-matematis rendah berjumlah 16 siswa. Hasil angket ini diambil dari hasil angket kelas kontrol dan eksperimen. Berdasarkan hasil angket kecerdasan majemuk logis-matematis bahwa sangat signifikan, berarti kelas kontrol dan eksperimen homogen.

\section{Pengujian Persyaratan Analisis Data}

\section{a. Uji Normalitas}

\section{1) Eksperimen}

Hipotesis yang diuji normalitasnya yaitu:

$\mathrm{Ha}$ : Kemampuan berpikir kritis melalui model pembelajaran abad 21 tipe Active Learning tidak berdistribusi normal.

Ho : Kemampuan berpikir kritis melalui pembelajaran model pembelajaran abad 21 tipe Active Learning berdistribusi normal.

Tabel 5 Hasil Perhitungan Normalitas Eksperimen dengan Lillifors

\begin{tabular}{|c|c|c|c|c|c|c|}
\hline $\mathbf{X i}$ & $\mathbf{F}$ & $\begin{array}{c}\text { Frekuensi } \\
\text { Kumulatif }\end{array}$ & $\mathbf{Z i}$ & $\mathbf{F}(\mathbf{Z i})$ & $\mathbf{S}(\mathbf{Z i})$ & $\begin{array}{c}\mathbf{F}(\mathbf{Z i})- \\
\mathbf{S}(\mathbf{Z i})\end{array}$ \\
\hline 37 & 1 & 1 & $-2,88$ & 0,1894 & 0,0625 & 0,1269 \\
\hline 38 & 2 & 2 & $-2,28$ & 0,0113 & 0,1875 & 0,1762 \\
\hline 39 & 1 & 4 & $-1,68$ & 0,0465 & 0,25 & 0,2030 \\
\hline 40 & 2 & 6 & $-1,08$ & 0,1401 & 0,375 & 0,2349 \\
\hline 41 & 3 & 10 & 0,39 & 0,625 & 0,486 & 0,1390 \\
\hline 42 & 6 & 16 & 0,11 & 0,8665 & 1,0000 & 0,1540 \\
\hline
\end{tabular}

Berdasarkan tabel 5 bahwa, Kolom F (Zi)-S (Zi). Pada tabel di atas di dapat nilai terbesar pada kolom F (Zi)-S (Zi) adalah 0,2234, maka $\mathrm{Lo}=0,2234$. Sedangkan nilai $\mathrm{L}_{\text {tabel }}$ untuk $\mathrm{n}=16$ yaitu 0,250 . Maka, dari hasil perhitungan $\mathrm{Lo}=0,234$ dan nilai $\mathrm{L}_{\text {tabel }}=0,250$ ternyata nilai Lo $<\mathrm{L}_{\text {tabel }}$ maka Ha diterima berarti sebaran data prestasi belajar distribusi Normal.

\section{2) Kontrol}

Hipotesis yang akan diuji normalitasnya:

$\mathrm{Ha}$ : Kemampuan berpikir kritis melalui mpeodel pembelajaran abad 21 tipe Pembelajaran Langsung tidak berdistribusi normal. 
Ho : Kemampuan berpikir kritis melalui model pembelajaran abad 21 tipe Pembelajaran Langsung berdistribusi normal.

Tabel 6 Hasil Perhitungan Normalitas Kontrol dengan Lillifors

\begin{tabular}{|c|c|c|c|c|c|c|}
\hline $\mathbf{X i}$ & $\mathbf{F}$ & $\begin{array}{c}\text { Frekuensi } \\
\text { Kumulatif }\end{array}$ & $\mathbf{Z i}$ & $\mathbf{F}(\mathbf{Z i})$ & $\mathbf{S}(\mathbf{Z i})$ & $\begin{array}{c}\mathbf{F}(\mathbf{Z i})- \\
\mathbf{S}(\mathbf{Z i})\end{array}$ \\
\hline 37 & 1 & 1 & $-1,41$ & 0,0043 & 0,0625 & 0,0189 \\
\hline 38 & 3 & 4 & $-0,66$ & 0,0418 & 0,25 & 0,2082 \\
\hline 39 & 1 & 5 & 0,09 & 0,2005 & 0,3125 & 0,112 \\
\hline 40 & 5 & 10 & 0,85 & 0,5119 & 0,625 & 0,1131 \\
\hline 41 & 3 & 13 & 1,60 & 0,8289 & 0,8125 & 0,0164 \\
\hline 42 & 3 & 16 & 2,36 & 0,9578 & 1,0000 & 0,0422 \\
\hline
\end{tabular}

Berdasarkan Kolom F (Zi)-S (Zi) pada tabel 6, di dapatkan nilai terbesar pada kolom F (Zi)-S (Zi) adalah 0,2234, maka $\mathrm{Lo}=0,208$. Sedangkan nilai $\mathrm{L}_{\text {tabel }}$ untuk $\mathrm{n}=16$ yaitu 0,250. Maka, dari hasil perhitungan $\mathrm{Lo}=0,208$ dan nilai $\mathrm{L}_{\text {tabel }}=0,250$ ternyata nilai $\mathrm{Lo}<\mathrm{L}_{\text {tabel }}$ maka Ha diterima berarti sebaran data prestasi belajar distribusi Normal.

\section{3) Active Learning Dengan Kecerdasan Logis-Matematis Tinggi (A1B1)}

Ha : Kemampuan berpikir kritis melalui model Active Learning dengan siswa yang memiliki kecerdasan logis-matematis tinggi tidak berdistribusi normal Ho : Kemampuan berpikir kritis melalui model Active Learning dengan siswa yang memiliki kecerdasan logis-matematis tinggi tidak berdistribusi normal Tabel 6 Hasil Perhitungan Normalitas A1B1 dengan Lillifors

\begin{tabular}{|c|c|c|c|c|c|c|}
\hline $\mathbf{X i}$ & $\mathbf{F}$ & $\begin{array}{c}\text { Frekuensi } \\
\text { Kumulatif }\end{array}$ & $\mathbf{Z i}$ & $\mathbf{F}(\mathbf{Z i})$ & $\mathbf{S}(\mathbf{Z i})$ & $\begin{array}{c}\mathbf{F}(\mathbf{Z i})- \\
\mathbf{S}(\mathbf{Z i})\end{array}$ \\
\hline 89 & 1 & 1 & $-3,74$ & 0,00001 & 0,1666 & 0,6665 \\
\hline 91 & 1 & 2 & $-1,16$ & 0,1230 & 0,3333 & 0,210 \\
\hline 93 & 2 & 4 & 0,12 & 0,4562 & 0,6666 & 0,2104 \\
\hline 95 & 4 & 8 & 0,82 & 0,7939 & 1,0000 & 0,2061 \\
\hline
\end{tabular}

Kolom F (Zi)-S (Zi). Pada tabel di atas di dapat nilai terbesar pada kolom F (Zi)-S (Zi) adalah 0,2104 , maka $\mathrm{Lo}=0,2104$. Sedangkan nilai $\mathrm{L}_{\text {tabel }}$ untuk $\mathrm{n}=8$ yaitu 0,285 . Maka, dari hasil perhitungan $\mathrm{Lo}=0,2104$ dan nilai $\mathrm{L}_{\text {tabel }}=0,285$ ternyata nilai $\mathrm{Lo}<\mathrm{L}_{\text {tabel }}$ maka $\mathrm{Ha}$ diterima berarti sebaran data prestasi belajar distribusi Normal.

\section{4) Active Learning Dengan Kecerdasan Logis-Matematis Rendah (A1B2)}

Ha : Kemampuan berpikir kritis melalui model Active Learning dengan siswa yang memiliki kecerdasan logis-matematis rendah tidak berdistribusi normal.

Ho : Kemampuan berpikir kritis melalui model Active Learning dengan siswa yang memiliki kecerdasan logis-matematis rendah berdistribusi normal.

Tabel 7 Hasil Perhitungan Normalitas A1B2 dengan Lillifors

\begin{tabular}{|r|r|c|c|c|c|c|}
\hline $\mathbf{X i}$ & $\mathbf{F}$ & $\begin{array}{c}\text { Frekuensi } \\
\text { Kumulatif }\end{array}$ & $\mathbf{Z i}$ & $\mathbf{F}(\mathbf{Z i})$ & $\mathbf{S}(\mathbf{Z i})$ & $\begin{array}{c}\mathbf{F}(\mathbf{Z i})-\mathbf{S} \\
(\mathbf{Z i})\end{array}$ \\
\hline 86 & 1 & 1 & $-1,28$ & 0,1003 & 0,125 & 0,025 \\
\hline
\end{tabular}




\begin{tabular}{|c|c|c|c|c|c|c|}
\hline 89 & 2 & 3 & $-0,45$ & 0,3264 & 0,375 & 0,048 \\
\hline 91 & 1 & 4 & 0,10 & 0,4602 & 0,5 & 0,039 \\
\hline 93 & 1 & 5 & 0,66 & 0,7454 & 0,625 & 0,120 \\
\hline 95 & 4 & 8 & 1,21 & 0,8869 & 1,0000 & 0,1131 \\
\hline
\end{tabular}

Kolom F (Zi)-S (Zi). Pada tabel di atas di dapat nilai terbesar pada kolom F (Zi)-S (Zi) adalah 0,120 , maka $L o=0,120$. Sedangkan nilai $L_{\text {tabel }}$ untuk $n=8$ yaitu 0,285 . Maka, dari hasil perhitungan $\mathrm{Lo}=0,120$ dan nilai $\mathrm{L}_{\text {tabel }}=0,285$ ternyata nilai $\mathrm{Lo}<\mathrm{L}_{\text {tabel }}$ maka Ha diterima berarti sebaran data prestasi belajar distribusi Normal.

\section{5) Pembelajaran Langsung Dengan Kecerdasan Logis-Matematis Tinggi (A2B1)}

$\mathrm{Ha}$ : Kemampuan berpikir kritis melalui model Pembelajaran Langsung dengan siswa yang memiliki kecerdasan logis-matematis tinggi tidak berdistribusi normal

Ho : Kemampuan berpikir kritis melalui model Pembelajaran Langsung dengan siswa yang memiliki kecerdasan logis-matematis tinggi berdistribusi normal

Tabel 8 Hasil Perhitungan Normalitas A2B1 dengan Lillifors

\begin{tabular}{|r|r|c|c|c|c|c|}
\hline $\mathbf{X i}$ & $\mathbf{F}$ & $\begin{array}{c}\text { Frekuensi } \\
\text { Kumulatif }\end{array}$ & $\mathbf{Z i}$ & $\mathbf{F}(\mathbf{Z i})$ & $\mathbf{S}(\mathbf{Z i})$ & $\begin{array}{c}\mathbf{F}(\mathbf{Z i})- \\
\mathbf{S}(\mathbf{Z i})\end{array}$ \\
\hline 86 & 1 & 1 & $-2,21$ & 0,0136 & 0,125 & 0,1114 \\
\hline 91 & 4 & 5 & $-0,24$ & 0,4052 & 0,625 & 0,2198 \\
\hline 93 & 1 & 6 & 0,54 & 0,7054 & 0,75 & 0,0446 \\
\hline 95 & 2 & 8 & 1,32 & 0,9066 & 1,0000 & 0,0934 \\
\hline
\end{tabular}

Kolom F (Zi)-S (Zi). Pada tabel di atas di dapat nilai terbesar pada kolom F (Zi)-S (Zi) adalah 0,2198 , maka $\mathrm{Lo}=0,2198$. Sedangkan nilai $\mathrm{L}_{\text {tabel }}$ untuk $\mathrm{n}=8$ yaitu 0,285 . Maka, dari hasil perhitungan $\mathrm{Lo}=0,2198$ dan nilai $\mathrm{L}_{\text {tabel }}=0,285$ ternyata nilai $\mathrm{Lo}<\mathrm{L}_{\text {tabel }}$ maka $\mathrm{Ha}$ diterima berarti sebaran data prestasi belajar distribusi Normal.

6) Pembelajaran Langsung Dengan Kecerdasan Logis-Matematis Rendah (A2B2)

Ha : Kemampuan berpikir kritis melalui model Pembelajaran Langsung dengan siswa yang memiliki kecerdasan logis-matematis rendah tidak berdistribusi normal

Ho : Kemampuan berpikir kritis melalui model Pembelajaran Langsung dengan siswa yang memiliki kecerdasan logis-matematis rendah berdistribusi normal

Tabel 9 Hasil Perhitungan Normalitas A2B2 dengan Lillifors

\begin{tabular}{|c|c|c|c|c|c|c|}
\hline $\mathbf{X i}$ & $\mathbf{F}$ & $\begin{array}{c}\text { Frekuensi } \\
\text { Kumulatif }\end{array}$ & $\mathbf{Z i}$ & $\mathbf{F}(\mathbf{Z i})$ & $\mathbf{S}(\mathbf{Z i})$ & $\begin{array}{c}\mathbf{F} \\
(\mathbf{Z i})-\mathbf{S} \\
(\mathbf{Z i})\end{array}$ \\
\hline 86 & 3 & 3 & $-1,56$ & 0,2327 & 0,375 & 0,142 \\
\hline 91 & 2 & 5 & $-0,32$ & 0,6217 & 0,625 & 0,003 \\
\hline 93 & 2 & 7 & 0,28 & 0,6103 & 0,875 & 0,264 \\
\hline 95 & 1 & 8 & 0,82 & 0,7939 & 1,0000 & 0,2061 \\
\hline
\end{tabular}

Kolom F (Zi)-S (Zi). Pada tabel di atas di dapat nilai terbesar pada kolom F (Zi)-S (Zi) adalah 0,264 , maka $L o=0,264$. Sedangkan nilai $L_{\text {tabel }}$ untuk $n=8$ yaitu 0,285 . Maka, dari 


\section{Educatio: Jurnal IImu Kependidikan}

Vol. 16, No 1 Juli 2021, hal. 9-23

http://e-journal.hamzanwadi.ac.id/index.php/edc

e-ISSN: 2527-9998

DOI: 10.29408/edc.v16i1.2770

hasil perhitungan $\mathrm{Lo}=0,264$ dan nilai $\mathrm{L}_{\text {tabel }}=0,285$ ternyata nilai $\mathrm{Lo}<\mathrm{L}_{\text {tabel }}$ maka Ha diterima berarti sebaran data prestasi belajar distribusi Normal.

\section{b. Uji Homogenitas}

Uji homogenitas pada penelitian ini menggunakan pengujian homogenitas perbandingan Varians. Adapun hipotesis yang akan diuji yaitu:

Ho : Data kelas A dan Kelas B homogen

Ha : Data kelas A dan kelas B tidak homogen

Homogenitas varians kedua kelompok sampel di atas adalah:

$F=\frac{\text { Varians terbesar }}{\text { varians terkecil }}$

$=\frac{1,481}{1,447}$

$=1,023$

Jadi, jumlah sampel adalah 16 , maka dk pembilang $=16-1=24$ dan dk penyebut $=16$ $-1=15$. Adapun harga $F_{\text {tabel }}$ untuk dk pembilang $=16$ dan dk penyebut $=24$ adalah 2,403 dan ternyata nilai $F_{\text {hitung }}<F_{\text {tabel }}$ atau $1,023<1,984$. Maka dapat disimpulkan bahwa varians kedua sampel tersebut adalah Homogen.

Setelah hasil dari kedua kelompok eksperimen dan kontrol di uji. Hasilnya berdistribusi normal dan homogen, berarti persyaratan analisis sudah terpenuhi. Jika telah terpenuhi, analisis bisa dilanjutkan ke uji hipotesis.

\section{Uji Hipotesis}

Pengujian hipotesis merupakan langkah atau prosedur untuk menentukan apakah hipotesis diterima atau ditolak. Data yang digunakan untuk uji hipotesis adalah data analisis angket kecerdasan majemuk logis-matematis dan hasil kemampuan berpikir kritis akhir kelas eksperimen dan kelas kontrol. Pengujian hipotesis dalam penelitian ini adalah:

\section{a. Pengujian Hipotesis 1}

Pengujian hipotesis dalam penelitian ini yaitu:

$\boldsymbol{H}_{\mathbf{0}}$ : Tidak terdapat perbandingan kemampuan berpikir kritis siswa yang dibelajarkan dengan model Active Learning lebih tinggi dibandingkan pembelajaran langsung.

$\mathrm{H}_{1}$ : Terdapat perbandingan kemampuan berpikir kritis siswa yang dibelajarkan dengan model Active Learning lebih tinggi dibandingkan pembelajaran langsung.

Hasil analisis data dengan menggunakan ANAVA dua jalur. Data menunjukkan ada perbandingan kemampuan berpikir kritis antara siswa yang belajar dengan menggunakan model active learning dan siswa yang dibelajarkan dengan menggunakan model pembelajaran langsung. Karena $F_{h}(K)=34,0593>4,15$, maka terdapat perbedaan yang signifikan antar kolom. Ini menunjukkan bahwa terjadi perbedaan hasil kemampuan berpikir kritis yang diajarkan dengan model Active Learning model pembelajaran langsung.

Di samping itu, bahwa pembelajaran dengan menggunakan pembelajaran active learning lebih baik dari pada pembelajaran langsung. Hal ini dapat dilihat dari perbandingan nilai rata-rata kemampuan berpikir kritis kelas eksperimen memiliki mean rata-rata dengan 92, 56 lebih tinggi dibandingkan rata-rata hasil belajar kelas kontrol sama dengan 90, 43. 


\section{Educatio: Jurnal IImu Kependidikan}

Vol. 16, No 1 Juli 2021, hal. 9-23

http://e-journal.hamzanwadi.ac.id/index.php/edc

e-ISSN: 2527-9998

DOI: 10.29408/edc.v16i1.2770

\section{b. Pengujian Hipotesis 2}

Pengujian hipotesis dalam penelitian ini yaitu:

$H_{0}$ : Tidak terdapat interaksi antara model pembelajaran dan kecerdasan majemuk terhadap kemampuan berpikir kritis siswa

$\mathrm{H}_{1}$ : Terdapat interaksi antara model pembelajaran dan kecerdasan majemuk terhadap kemampuan berpikir kritis siswa

Hasil analisis data dengan menggunakan ANAVA dua jalur. Data menunjukkan ada interaksi model pembelajaran abad 21 tipe active learning dan pembelajaran langsung dengan kecerdasan majemuk logis-matematis. Karena Fh (interaksi) $=40,0293>4,15$, maka terdapat interaksi antara faktor kolom dan kelompok. Ini menunjukkan bahwa terdapat interaksi antara model active learning dan pembelajaran langsung dengan kecerdasan majemuk logis-matematis.

\section{c. Pengujian Hipotesis 3}

Pengujian hipotesis pada penelitian ini yaitu:

$H_{0}$ : Tidak terdapat perbedaan kemampuan berpikir kritis siswa yang memiliki kecerdasan majemuk logis-matematis tinggi dan rendah.

$\mathrm{H}_{1}$ : Terdapat perbedaan kemampuan berpikir kritis siswa yang memiliki kecerdasan majemuk logis-matematis tinggi dan rendah.

Hasil analisis data dengan menggunakan ANAVA dua jalur. Data menunjukkan tidak ada perbedaan yang sangat signifikan. Karena Fh $(b)=0,752<4,15$, maka tidak terdapat perbedaan yang antar baris. Ini menunjukkan bahwa tidak ada perbedaan hasil belajar siswa yang memiliki kecerdasan majemuk logis-matematis tinggi dan logis-matematis rendah.

\section{d. Pengujian Hipotesis 4}

Pengujian hipotesis pada penelitian ini yaitu:

$H_{0}$ : Tidak terdapat perbedaan kemampuan berpikir kritis antara siswa yang dibelajarkan dengan model active learning dan pembelajaran langsung pada siswa yang memiliki tingkat kecerdasan majemuk logis-matematis tinggi dan rendah.

$\mathrm{H}_{1}$ : Terdapat perbedaan kemampuan berpikir kritis antara siswa yang dibelajarkan dengan model active learning dan pembelajaran langsung pada siswa yang memiliki tingkat kecerdasan majemuk logis-matematis tinggi dan rendah.

Hasil analisis data dengan menggunakan ANAVA dua jalur. Data menunjukkan terdapat perbedaan antara kelompok model active learning dengan kecerdasan majemuk logismatematis tinggi dengan rendah, begitu juga dengan model pembelajaran abad 21 tipe pembelajaran langsung. Karena Fh $(\mathrm{AK})=34,0593>3,32$, maka terdapat perbedaan antar kelompok model active learning dan Pembelajaran langsung dengan kecerdasan logismatematis tinggi dan rendah.

\section{A. Pembahasan}

1. Terdapat Perbandingan Kemampuan Berpikir Kritis Siswa yang Dibelajarkan Dengan Model Active Learning Lebih Tinggi Dibandingkan Pembelajaran Langsung 


\section{Educatio: Jurnal IImu Kependidikan}

Vol. 16, № 1 Juli 2021, hal. 9-23

http://e-journal.hamzanwadi.ac.id/index.php/edc

e-ISSN: 2527-9998

DOI: 10.29408/edc.v16i1.2770

Berdasarkan hasil pengujian hipotesis menggunakan uji ANAVA menunjukkan terdapat perbedaan yang signifikan antar kolom. Hasil ini didukung oleh penelitian Sholehudin (2013), penelitiannya menunjukkan kemampuan berpikir kritis siswa, menunjukkan model active learning lebih tinggi dari model pembelajaran langsung.

Model active learning memiliki karakteristik menurut Bonwell (Daryanto dan Karim, 2017), bahwa peserta didik dituntut untuk berfikir kritis, menganalisis dan melakukan evaluasi. Berbeda dengan pembelajaran langsung ditekankan kepada penanaman konsep terhadap peserta didik (Daryanto dan Karim, 2017). Jadi dari perbedaan karakteristik tersebut, active learning lebih mampu meningkatkan kemampuan berpikir kritis dibandingkan dengan pembelajaran langsung.

Beberapa penelitian membuktikan perhatian siswa akan berkurang bersamaan dengan berlalunya waktu. Penelitian pollio (Ramlah, 2018) menunjukkan bahwa siswa dalam ruang kelas hanya memperhatikan pembelajaran sekitar $40 \%$ dari waktu pembelajaran. Sedangkan, penelitian McKeachy (Muhajirin \& Ratnawati, 2016), bahwa dalam 10 menit pertama, perhatian siswa mencapai $70 \%$, dan berkurang sampai menjadi $20 \%$ pada waktu 20 menit terakhir. Jadi, pembelajaran lebih efektif apabila mampu mengikat ketiga gaya belajar yaitu Auditori (pendengaran), Visual (Penglihatan) dan kinestetik (Gerak). Model yang mampu mengikat ketiga gaya belajar tersebut yaitu model active learning.

2. Terdapat Interaksi Antara Model Active Learning Dan Kecerdasan Majemuk Logis-

\section{Matematis Terhadap Kemampuan Berpikir Kritis Siswa}

Hasil penelitian ini menunjukkan interaksi antara model active learning dengan kecerdasan majemuk logis-matematis terhadap kemampuan berpikir kritis. Selain itu, ketiga variabel tersebut terdapat interaksi dapat dilihat dari keterkaitan dari ketiga variabel tersebut yaitu: active leraning model menekankan kepada kemampuan berpikir kritis (Daryanto dan Karim, 2017). Kecerdasan majemuk logis-matematis menurut Piaget (Jasmine, 2019), mencirikan kecerdasan ini sebagai pemikiran kritis karena orang dengan kecerdasan ini gemar mengumpulkan dan mengorganisasi, mengabalisis serta menginterpretasikan, menyimpulkan kemudian meramalkan. Sedangkan kemampuan berpikir kritis merupakan salah satu kompetensi yang diharapkan oleh model pembelajara abad 21.

Berdasarkan uraikan dari ketiga variabel tersebut terdapat interaksi karena active learning dan kecerdasan majemuk logis-matematis terhadap kemampuan berpikir kritis. Karena, disarkan hasil penelitian, penelitian sebelumnya dam memiliki kompetensi yang dicirikan mengacu kepada kemampuan berpikir kritis

\section{Terdapat Perbedaan Kemampuan Berpikir Kritis Siswa yang Memiliki Kecerdasan Majemuk Logis-Matematis Tinggi dan Rendah}

Hasil penelitian tidak terdapat perbedaan kemampuan berpikir kritis siswa Pada kemampuan berpikir kritis siswa untuk mengetahui perbedaan bagi siswa yang memiliki kecerdasan majemuk logis-matematis tinggi dan rendah.

Hipotesis tertolak karena responden yang sedikit dan hasil dari siswa yang memiliki kecerdasan logis-matematis tinggi dengan siswa yang memiliki kecerdasan logis-matematis rendah memiliki selisih yang kecil. Hal ini sesuai dengan pendapat Nisfiannor (2009: 9) mengatakan hipotesis ditolak disebabkan karena: 1) salah dalam pemilihan teori, 2) salah 


\section{Educatio: Jurnal IImu Kependidikan}

Vol. 16, No 1 Juli 2021, hal. 9-23

http://e-journal.hamzanwadi.ac.id/index.php/edc

e-ISSN: 2527-9998

DOI: 10.29408/edc.v16i1.2770

dalam pengambilan sampel, 3) salah dalam penentuan alat pengampilan data, 4) salah dalam perhitungan statistik dan pembuatan rancangan penelitian.

Akan tetapi, berdasarkan analisis ternyata siswa yang dibelajarkan menggunakan active learning dengan siswa yang memiliki kecerdasan majemuk logis-matematis tinggi menunjukkan lebih tinggi dari pada siswa yang dibelajarkan menggunakan pembelajaran langsung dengan siswa yang memiliki kecerdasan logis matematis tinggi. Begitu juga dengan hasil dari analisis kemampuan berpikir kritis siswa yang dibelajarkan menggunakan model pembelajaran abad 21 tipe active learning dan pembelajaran langsung, dengan siswa yang memiliki kecerdasan majemuk logis-matematis rendah, menunjukkan active learning lebih tinggi daripada pembelajaran langsung. Jadi dapat disimpulkan dari kedua perbedaan tersebut, bahwa terdapat perbedaan antara siswa dengan kecerdasan majemuk tinggi maupun rendah.

Dapat diuraikan bahwa, hasil kemampuan berpikir kritis menunjukkan perbedaan antara siswa yang memiliki kecerdasan logis-matematis tinggi dengan siswa yang memiliki kecerdasan logis matematis rendah. Tetapi setelah diuji hipotesisnya melalui ANAVA dua jalur mengatakan $\mathrm{H}_{0}$ diterima dan $\mathrm{H}_{\mathrm{a}}$ ditolak. Karena salah satu yang membuat hipotesis ini ditolak karena responden yang sedikit dan hasil dari siswa yang memiliki kecerdasan logis-matematis tinggi dengan siswa yang memiliki kecerdasan logis-matematis rendah memiliki selisih yang kecil.

4. Terdapat Perbedaan Kemampuan Berpikir Kritis Antara Siswa yang Dibelajarkan Dengan Model Active Learning dan Pembelajaran Langsung Pada Siswa Yang Memiliki Tingkat Kecerdasan Logis-Matematis Tinggi dan Rendah

Perbedaan kemampuan berpikir kritis antara keempat kelompok yang sudah digolongkan dari siswa yang memiliki kecerdasan majemuk logis-matematis tinggi dan rendah pada kedua model yang dibelajarkan yaitu active learning dan logis-matematis. Perbedaan antar kelompok tersebut berdasarkan analisi kemampuan berpikir kritis diantaranya: 1) kelompok active learning dengan siswa yang memiliki kecerdasan logis-matematis tinggi nilai rata-rata 93, 25, 2) kelompok active learning dengan siswa yang memiliki kecerdasan logis-matematis rendah nilai rata-rata 90, 625, 3) kelompok pembelajaran langsung siswa yang memiliki kecerdasan logis-matematis tinggi nilai rata-rata 90,625,4) kelompok pembelajaran langsung siswa yang memiliki kecerdasan logis-matematis rendah nilai rata-rata 90, 125. Jadi, dapat dilihat dari keempat kelompok tersebut memiliki rata-rata yang berbeda sehingga terdapat perbedaan antar kelompok.

Jadi, dapat diuraikan bahwa terdapat perbedaan kemampuan berpikir kritis antara siswa yang dibelajarkan dengan model pembelajaran abad 21 tipe active learning dan pembelajaran langsung pada siswa yang memiliki tingkat kecerdasan tinggi dan rendah.

\section{SIMPULAN}

Pengaruh model pembelajaran abad 21 tipe active learning dan kecerdasan majemuk terhadap berpikir kritis siswa dapat disimpulkan sebagai berikut:

1. Terdapat perbedaan antara model pembelajaran abad 21 tipe active learning dengan pembelajaran langsung berdasarkan hasil hipotesis, $\mathrm{F}_{\mathrm{h}}(\mathrm{K})=34,0593>4,15$. 
2. Terdapat interaksi model pembelajaran abad 21 tipe active learning dan pembelajaran langsung dengan kecerdasan majemuk logis-matematis berdasarkan hasil hipotesis Fh (interaksi) $=40,0293>4,15$.

3. Tidak menunjukkan perbedaan kemampuan berpikir kritis siswa yang Memiliki kecerdasan majemuk tinggi dan rendah. Berdasarkan hasil hipotesis Fh (b) $=0,752<4,15$.

4. Terdapat perbedaan kemampuan berpikir kritis antara siswa yang dibelajarkan dengan model active learning dan pembelajaran langsung pada siswa yang memiliki tingkat kecerdasan logis-matematis tinggi dan rendah karena. Berdasarkan hasil hipotesis $\mathrm{Fh}(\mathrm{AK})=34,0593>$ 3,32 .

\section{PERNYATAAN PENULIS}

Penulis menyatakan bahwa artikel ini belum pernah diterbitkan dalam jurnal manapun

\section{DAFTAR PUSTAKA}

Andre \& Trisna. (2018). Panduan Penelitian Beserta Analisis Statistik dengan SPSS. Yogyakarta: Deepublis

Creswell, J. W. (2009). Research design: Qualitative, quantitative, and mixed methods research.

Thousand Oaks, CA: Sage Publications, Inc. and Mathematics Anxiety in Mathematics Problem-Solving Efficiency. Learning and Individual Differences, 20(3), 276-283.

Faradila, Nisrina. (2019). Menilik Kualitas Pendidikan di Indonesia Menurut PISA 3 Periode Terakhir. Di unduh 11 Juli 2020. Http://www. google.com /amp/s/m.kumparan .com/amp/kumparansains/menilik-kualitas-pendidikan-indonesiamenurut-pisa-3-periode-terakhir-1sOo0SIXNroC

Hosnan, M. (2014). Pendekatan saintifik dan kontekstual dalam pembelajaran abad 21: Kunci sukses implementasi kurikulum 2013. Ghalia Indonesia.

Jamaris, M. (2017). Pengukuran Kecerdasan Jamak. Bogor: Ghalia Indonesia.

Jasmine, J. (2012). Metode mengajar multiple intelligences. Bandung: Nuansa Cendekia.

Karim \& Daryanto. (2017). Pembelajaran Abad, 21. Malang: Gava Media

Muhajirin, M., \& Ratnawati, R. (2016). Pemanfaatan Aplikasi Berbasis Teknologi Informasi Dan Komunikasi Pada Taman Pengajian Al-Qur'an Nurul Muhammad Dan Miftahul Khair. Inspiration: Jurnal Teknologi Informasi Dan Komunikasi, 6(2).

Nisfiannor, Muhammad. (2009). Pendekatan Statistika Modern Untuk Ilmu Sosial. Jakarta: Salemba Humaneka

Putri, Widya A. Alasan Mengapa Kualitas PISA Siswa Indonesia Buruk. di unduh 11 Juli 2020. https://www.google/amp/s/amp.tirto.id/alasan-mengapa-kualitas-pisaindonesia-buruk enfy.

Ramlah, S. (2018). Strategi Pembelajaran Pendidikan Kewarganegaraan Pokok Bahasan Perlindungan dan Penegakan Hak Asasi Manusia dengan Model Active Learning untuk Meningkatkan Hasil Belajar Siswa Kelas X MIA-4 SMA Negeri 3 Mataram. Jurnal 
Educatio: Jurnal IImu Kependidikan Vol. 16, No 1 Juli 2021, hal. 9-23 http://e-journal.hamzanwadi.ac.id/index.php/edc

e-ISSN: $2527-9998$ DOI: 10.29408/edc.v16i1.2770

Kependidikan: Jurnal Hasil Penelitian Dan Kajian Kepustakaan Di Bidang Pendidikan, Pengajaran Dan Pembelajaran, 4(1), 98-102. 